Birutè Obelenienè*

Lithuania

Andrius Narbekovas*

Department of Theology of Vytautas Magnus University, Kaunas

\title{
Human dignity as a universal moral dimension of the preparation of youth for marriage and family life
}

\section{Introduction}

Throughout all human history of raising and educating children, nothing better and more appropriate than a family has been found. It is the main reason why the family is the fundamental good of a person, society and state. Today, in the face of the cultural challenge caused by "gender ideology" (which denies the difference and reciprocity in nature of a man and a woman

* Birute Obeleniene, a doctor of social science (science of education), a professor of Theology Department and a senior researcher of Research Center on Marriage and Family of the Catholic Theology Faculty at Vytautas Magnus University, Lithuania. Research interests: sexual ethics, bioethics, preparation for youth to family life.

* Rev. Andrius Narbekovas, MD, a doctor and professor of theology, the head of Theology Department, the head of Research Center on Marriage and Family of the Catholic Theology Faculty at Vytautas Magnus University, Lithuania. Research interests: bioethics, conjugal and medical ethics. 
and anticipates a society without gender differences, thereby removing the anthropological foundation of family), a dramatically lowered birth rate and the collapse of the family institution, there is no need to argue that in order to survive as a nation and a human race, the main goal must be the preparation of young people for marriage and family. Today it is very important to purify moral principles, which could become a cornerstone for youth's preparation for family life. Human dignity could become a universal dimension of the preparation for family life since it is a strong category and an integral part of the fact of human existence from which all inalienable human rights arise.

The goal of the paper: To present the basic elements of the preparation of youth for marriage and family life based on the conception of human dignity.

Tasks of the paper: 1) To describe the concept of human dignity; 2) To distinguish the features of basic elements of the preparation of youth to marriage and family life.

\section{The definition of human dignity}

The Universal Declaration of Human Rights, which became the basis for subsequent international instruments and conventions, starts with the recognition that foundation of freedom, justice and peace in the world lies in "the inherent dignity and the equal and inalienable rights of all members of the human family." However, paradoxically, the term "human dignity," although being part of the content of many international laws and national constitutions, is perceived ambiguously. ${ }^{2}$ According to Professor J. Juškevičius, there are various philosophical, political and ethical concepts of human dignity, and for this reason, there are often objections to the content of this concept. In scientific literature, many interpretations of it exist, the contents

1 The Universal Declaration of Human Rights adopted and published by the UN General Assembly on 10 December 1948 by resolution 217A, http://www.ohchr.org/EN/UDHR/ Documents/UDHR_Translations/eng.pdf.

2 A. Taminskas, G. Mesonis, Žmogaus orumas: konstitucinès refleksijos, "Jurisprudencija” 2014 No. 21 (4), p. 958. 
of which are heavily dependent on representatives of which branch of science interpret it. ${ }^{3}$

In the most general sense, according to A. Vaišvila, ${ }^{4}$ the concept of human dignity can be defined in accordance with two different positions, which are determined by the origin of human dignity: 1) dignity is associated with the very being of a human, dignity is an a priori characteristic of a human: It is neither assigned to oneself nor given by other people or society. Therefore, no one can take away the right to human dignity; 2) dignity of a human is given by others, and/or established by a human themselves.

The first concept of a human dignity is traced from the biblical tradition (the Christian concept of dignity is based on it as well): mankind is created "in God's image and likeness" (Gen 1:26-27). ${ }^{5}$ The second concept arises from a human's merit/utility to live properly in society. According to the latter concept, the meanings of dignity do not direct themselves to their initial origins because the essence of dignity is not defined through its reason and properties that constitute it, but rather through the final result - the value of a human being. ${ }^{6}$ The accent of coping with different concepts of dignity could be Immanuel Kant's assumption that dignity is what most distinguishes man from other animals. ${ }^{7}$ In this regard, asserting the contrary, i.e. that the common human dignity, inherent to each person, differs depending on the person's situation, legal or other status (which is determined by public rating), we would have to hold the dubious conclusion that not all people are equally different from other animals. ${ }^{8}$

3 J. Juškevičius, Kai kurie teisès i gyvybę prenataliniu laikotarpiu probleminiai aspektai, "Sveikatos mokslai" 2007 No. 17 (2), pp. 764-774.

4 A. Vaišvila, Žmogaus orumas ir teisé ị oruma teisinio personalizmo požiūriu (nuo statiškojo prie tampančiojo orumo sampratos), "Jurisprudencija" 2005 No. 71 (63), pp. 49-61.

5 "The dignity of the human person is rooted in his creation in the image and likeness of God," Catechism of the Catholic Church, 1700, http://www.vatican.va/archive/ENG0015/_ INDEX.HTM (henceforth CCC).

6 A. Vaišvila, Žmogaus orumas ir teise ị oruma teisinio personalizmo požiūriu (nuo statiškojo prie tampančiojo orumo sampratos), "Jurisprudencija" 2005, t. 71 (63), pp. 49-61.

7 I. Kantas, Grynojo proto kritika, Vilnius 1982, p. 73 (English version: I. Kant, Critique of pure reason, transl. and ed. by P. Guyer and A. W. Wood, New York 2008, available at: http:// strangebeautiful.com/other-texts/kant-first-critique-cambridge.pdf)

8 A. Taminskas, G. Mesonis, Žmogaus orumas: konstitucinés refleksijos, "Jurisprudencija” (2014) No. 21 (4), p. 965. 


\section{The background of the preparation of youth for marriage and family life based on the Christian concept of human dignity}

\section{The uniqueness of human nature}

As mentioned above, the Christian concept of human dignity is derived from the biblical tradition. By the act of creation, a human was awarded a unique nature, characterized by the "unity of body and spiritual soul," ${ }^{\text {in which }}$ body and spiritual soul are not two separate human parts, but rather their union that forms a single nature. ${ }^{10}$ The fact that a human is "the only creature on earth that God has willed for its own sake," only human is "able to know and love his creator" and that "he alone is called to share, by knowledge and love, in God's own life [...] is the fundamental reason for his dignity."11 Only because a human was created in a special way, unlike any other creations on the Earth, only a human has unique characteristics: he is "rational and therefore like God; he is created with free will and is master over his acts."12 A human is the only moral being because only those who are rational and free can be morally responsible. Under any circumstances, a human cannot become a means to another person. ${ }^{13}$ It is against the very human nature to use a person as a tool or an instrument to achieve a goal perceived by another subject. ${ }^{14} \mathrm{~A}$ human was gifted with life by the Creator by an exclusive action: only when creating a human, God said, "Let us make..." (Gen 1:26). While making everything else, God said, "Let there be light [...] vault [...] the seas" (Gen 1:4-10), "Let the land produce vegetation..." (Gen 1:12), "Let them be lights" (Gen 1:15-16), "Let the water teem with living creatures" (Gen 1:20),

9 "The human person, created in the image of God, is a being at once corporeal and spiritual," CCC 362.

10 CCC 365.

11 CCC 356.

12 CCC 1730.

13 "Being in the image of God the human individual possesses the dignity of a person, who is not just something, but someone. He is capable of self-knowledge, of self-possession and of freely giving himself and entering into communion with other persons and he is called by grace to a covenant with his Creator, to offer him a response of faith and love that no other creature can give in his stead," CCC 357.

14 A. Narbekovas, K. Meilius, Biotechnologijos: pagalba ar iššūkis šeimai kaip institucijai?, "Sveikatos mokslai" 2002 No. 18 (2), pp. 84-91. 
"Let the land produce living creatures" (Gen 1:24). The said phrase "let us make," unlike the phrase "let there be," elevates a human to a completely new level, because a human is connected with God in a special way. Through life that was gifted to humans, "God shares himself with his creation." 15 Therefore, a human cannot apply the same rules in relation to another human and to himself as to all the other creations. For this fundamental reason, a human's coming into this world must be fundamentally different, as well. Only animals need just females and males for reproduction. Thus, humans themselves must give life to their children, only through a personal act that derives from love.

\section{Love - a central component of the preparation}

for marriage and family life

The transmission of life to another human, first of all, needs to be human. ${ }^{16}$ Its first condition arises from the fact that a human was made by the Creator out of love for him, "willed for his own sake" and personally. Only a human "is called to love and to self-giving in the inseparable unity of body and spirit." Only a human has "the capacity of expressing love: that love precisely in which the man-person becomes a gift and - by means of this gift - fulfils the very meaning of his being and existence. Every form of love will always bear this masculine and feminine character."17 It is often believed that love is something already made in human relations. It is believed that there is no need to develop the ability to love, that love is given to a human as a certain type of heart adventure. ${ }^{18}$ Love should be seen as something which in a sense never is but always is becoming. And what it becomes, depends upon the contribution of both persons and the depth of their commitment ${ }^{19}$ and their ability to transfer their thoughts and feelings from sexual values of the one person to the other person's values. Experiences which have their roots in sensuality or natural

15 John Paul II, Encyclical letter Evangelium Vitae 34, http://w2.vatican.va/content/johnpaul-ii/en/encyclicals/documents/hf_jp-ii_enc_25031995_evangelium-vitae.html.

16 A. Narbekovas, K. Meilius, Biotechnologijos..., pp. 84-91.

17 The Pontifical Council for the Family, The truth and meaning of human sexuality. guidelines for education within the family, 10, http://www.vatican.va/roman_curia/pontifical_ councils/family/documents/rc_pc_family_doc_08121995_human-sexuality_en.html.

18 Cf. K. Wojtyła, Meile ir atsakomybe (Love and responsibility), Vilnius 1994, p. 174 (English version: Love and responsibility, transl. H. T. Willetts, London-New York 1981).

19 Cf. K. Wojtyła, Meile ir atsakomybe ..., p. 174. 
sensitivity of a woman or a man constitute only the material of love. ${ }^{20}$ Man as a complex multi-layered being manifests himself through various kinds of dynamism. Love involves bodily, mental, and spiritual dimensions ${ }^{21}$ that reveal in different ways:

- Sensual level: sexual desire $\rightarrow$ sensuality (sexuality);

- Psychic level: emotions, feelings $\rightarrow$ sensitivity (expression of feelings and emotions);

- Spiritual level: interpersonal relationships $\rightarrow$ affirmation of the other person's value.

The integration of these three dimensions is not something spontaneous but rather a program of making oneself whole, fulfilling oneself. The task is to create love from what is given by nature, freeing oneself primarily from the attitude of use because love is the opposite of use. ${ }^{22}$

The human ability to love is inseparable from his sexuality. Love needs to mature. Adolescents are still unable to take responsibility and concern for another person because they do not have the necessary moral power. Therefore, education for love is the central component of moral dimension of the preparation for family life. In addition, chastity is the main condition of child's and adolescent's maturing for love. The ideal of chastity is needed for young people not as a denial of their nature but as training how to control oneself, as an inspiring human example of what may be achieved by human will, as maturing them for their human vocation - to love.

\section{An authentic context of the origins of human life}

The unique nature of a human requires that human procreation must be completely authentic, including human sexuality, a man's and a woman's different ways of being, and their mutual complementarity because "the sexual identity of the person is not a cultural or social construction. It belongs to the specific manner in which the imago Dei exists." ${ }^{23}$ Only human children and parents live in a special relationship that is initiated before

20 Cf. K. Wojtyła, Meile ir atsakomybé..., p. 174.

21 Cf. K. Wojtyla, Meile ir atsakomybè..., p. 180.

22 Cf. K. Wojtyla, Meile ir atsakomybè..., p. 26.

23 International Theological Commission, Communion and stewardship: human persons created in the image of God, 33, http://www.vatican.va/roman_curia/congregations/cfaith/cti_ documents/rc_con_cfaith_doc_20040723_communion-stewardship_en.html. 
the child's birth and continues until the very end of their lives. Human fatherhood and motherhood essentially and exclusively are "similar" to the ones of God. Family is based on this similarity, and family is considered to be the community of human life, the community of people united by love (communio personarum). ${ }^{24}$ Thus, human life has to be transmitted according to the human nature and the conditions that are most favourable for a child to be conceived, grow and develop. In other words, the "origin of human life has its authentic context in marriage and in the family, where it is generated through an act which expresses the reciprocal love between a man and a woman. Procreation [...] 'must be the fruit of marriage." 25 Only this way is appropriate for human procreation, and only this way guarantees both the dignity of spouses, who with this act acquire new status of mother and father, and that of a conceived human. "The conjugal act, which is proper and specific to the unitive and procreative love between the spouses, an act which of its very nature is irreplaceable." 26 In terms of the transmission of human life, it is even completely unsuitable to use the term "reproduction," which is used to discuss animal body parts and processes of breeding, as it completely does not conform with human dignity.

The indispensability of human dignity and human life

It goes without saying that human life and dignity comprise the integrity of a human. There is no person without life, or without their inherent dignity. In other words, there is no human dignity without human life and vice versa. The Constitutional Court of Lithuania, revealing the constitutional concept of human dignity, stated that human life and dignity constitute the integrity of a person, mean the essence of a human, therefore, human life and dignity, as expressing the human integrity and unique essence, is above the law. ${ }^{27}$ The

\footnotetext{
24 A. Narbekovas, Vaisingumas asmens savybe , "Sveikatos mokslai" 2011 No. 21 (3), pp. 5-11.

25 Congregation for the Doctrine of the Faith, Instruction Dignitas Personae on certain bioethical questions, 6, http://www.vatican.va/roman_curia/congregations/cfaith/documents/ rc_con_cfaith_doc_20081208_dignitas-personae_en.html.

26 The Pontifical Council for Pastoral Assistance to Health Care Workers, The Charter for Health Care Workers, 22, https://www.ewtn.com/library/CURIA/PCPAHEAL.HTM (11.11.2016).

27 The ruling of the Lithuanian Constitutional Court, which mainly addressed the issue of one of the sanctions imposed by the criminal law - the constitutionality of the death penalty (resolution of 9 December 1998).
} 
content of the preparation for family life must clearly and unambiguously state that human life begins at the moment of conception. The knowledge that a human embryo is human life must play a crucial role in the formation of human conscience, because in an ambiguous situation, only conscience can dictate which action is good and which is bad. False conscience, for instance, if based on false information, simply enslaves and destroys personal freedom. ${ }^{28}$ If it is recognized that human life does not begin at the moment of conception, then abortion will not terminate human life and no moral problems should arise. However, if it is human life, then "the moral principles of respect and inviolability" 29 must be applied. As it is already proven by natural science, human life begins at conception. "The human embryo has, therefore, from the very beginning, the dignity proper to a person" ${ }^{30}$ and from the moment of conception it must have recognized rights as a person.

Today, the term "a person," used in international treaties, ${ }^{31}$ also includes the unborn child, and therefore human dignity is protected since its conception. ${ }^{32}$

Summarizing what has been discussed in this article, it is possible to distinguish four features of human dignity that the preparation of youth for marriage and family life should be based on. Each feature has its own indicators:

\section{Uniqueness of human nature}

- unity of spiritual soul and body implies the indispensability of love (as a spiritual action) and procreation (as a bodily action),

28 D. N. Irving, The woman and the physician facing abortion: The role of correct science in the formation of conscience and the moral decision making process, "The Linacre Quarterly" 67 (2000) No. 4, http://epublications.marquette.edu/cgi/viewcontent.cgi?article $=2237 \&$ context=lnq.

29 H. A. M. Have, R. H. J. Meulen, E. Leeuwen, Medicinos etika, Vilnius 2003, p. 283.

30 Congregation for the Doctrine of the Faith, Instruction Dignitas Personae 5.

31 Convention for the Protection of Human Rights and Dignity of the Human Being with regard to the Application of Biology and Medicine: Convention on Human Rights and Biomedicine, signed on 4 April, 1997. Lithuania ratified it on 17 October 2002. The explanatory report of the Convention, approved by the Committee of the Council of Europe, states that human dignity and identity have to be respected from "the moment of conception." See: Additional Protocol to the Convention for the Protection of Human Rights and Dignity of the Human Being with regard to the Application of Biology and Medicine, on the Prohibition of Cloning Human Beings, https://www.coe.int/en/web/conventions/full-list/-/conventions/ rms/090000168007f2ca. J. Juškevičius, J. Juškevičius, Negimusio vaiko teisinio statuso klausimai. Medicina etika ir teisé apie žmogų iki gimimo. Monografija (Sud. A. Narbekovas, E. Obelenienè), Kaunas 2012, p. 264.

32 J. Juškevičius, Negimusio vaiko teisinio..., pp. 234-277. 
- a human is rational; he/she can get to know and control themselves,

- a human is free, i.e. he/she has free will and can decide for themselves,

- a human has inherent dignity, which is specific only to him/her, and cannot be used by or cannot be the subject for another person,

- a human is a corporeal, sexual person (a woman or a man).

2. Love - developing relation:

- love is a task that needs to be sought through the integration of "love material" - sensitivity and sensuality given by nature,

- chastity is a prerequisite for the acquisition of the ability to love,

- sexual desire is a generational power.

3. Respect for life

- human life begins at the moment of conception,

- a human embryo from the very beginning has inherent dignity of a person.

4. An authentic context of the origin of human life

- parents give life to their child directly and through conjugal act; a conjugal act is:

- only between spouses,

- unconditional gifting,

- open to life (cognition of fertility and natural family planning [NFP]).

- procreation happens only in family consisting of one man and one woman on the basis of marriage.

As already mentioned, love is the central component in the preparation for family life. The visual model of the background of the preparation of youth for family life, based on the concept of human dignity, is shown in Figure 1.

\section{Conclusions}

- In terms of the origin of human dignity, we can state that there are two distinct concepts of dignity: 1) human dignity is inherent a priori, i.e. it is not given by another person or society, so no one can take it away; 2) human dignity is given by others, and/or established by a human themselves. The Christian concept of human dignity derives from the biblical tradition, where a human is created in God's image and likeness. Human life is inseparable from human dignity; 
Figure 1. Model of the background of the preparation of youth to marriage and family based on the Christian concept of human dignity

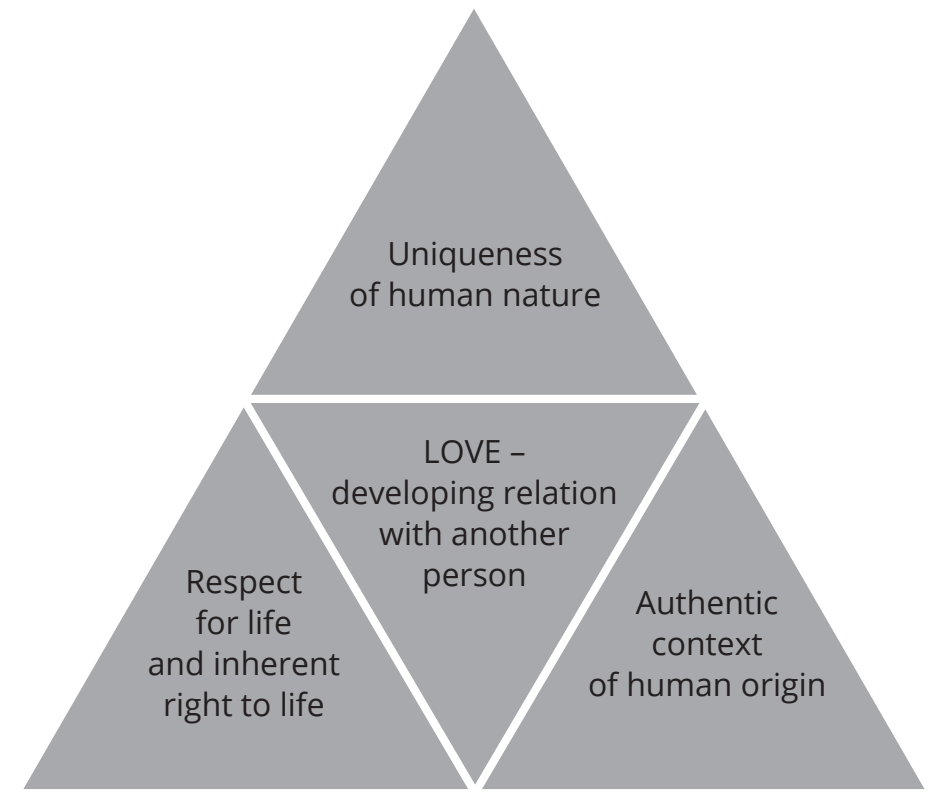

therefore, the principles of the preparation of youth for marriage and family life must be based on respect for human life, as well.

- This article presents the background of the preparation for family life based on the Christian concept of human dignity. It is expressed as a system of features and their indicators, making it suitable for the curriculum assessment. Four features are distinguished: 1) uniqueness of human nature, which is disclosed by 5 indicators: unity of spiritual soul and body implies the indispensability of love (as a spiritual action) and procreation (as a bodily action); a human is intelligent - he/she can get to know and control themselves; a human is free, i.e. he/she has free will and can decide for themselves; a human has an unparalleled value and inherent dignity that are specific only to him/her; by their nature, he/she cannot be used by and cannot be the subject for another person; a human is a corporeal, sexual person (a male or a female); 2) love is a central feature, which is disclosed by 3 indicators: love is a task which needs to be sought through the integration of "love material" - sensitivity 
and sensuality given by nature; chastity is a prerequisite for the acquisition of the ability to love; sexual desire is a generational power; 3 ) the right to life, which is disclosed by 2 indicators: human life begins at the moment of conception; a human embryo from the very beginning has inherent dignity of a person; 4 ) authentic context of the origin of human life, which is disclosed by 3 indicators: a child is a visible embodiment of love, a gift; parents transmit life to their child directly and through a conjugal act; procreation happens only in a family consisting of one man and one woman on the basis of marriage.

\section{Bibliography}

Catechism of the Catholic Church, http://www.vatican.va/archive/ENG0015/_ INDEX.HTM.

Congregation for the Doctrine of the Faith, Instruction Dignitas Personae on certain bioethical questions, http://www.vatican.va/roman_curia/congregations/ cfaith/documents/rc_con_cfaith_doc_20081208_dignitas-personae_en.html.

International Theological Commission, Communion and stewardship: human persons created in the image of God http://www.vatican.va/roman_curia/congregations/cfaith/cti_documents/rc_con_cfaith_doc_20040723_communionstewardship_en.html.

Have H. A. M., Meulen R. H. J., Leeuwen E., Medicinos etika, Vilnius 2003.

Irving D., The woman and the physician facing abortion: the role of correct science in the formation of conscience and the moral decision making process, "The Linacre Quarterly" 67 (2000) No. 4, http://epublications.marquette.edu/cgi/ viewcontent.cgi?article $=2237 \&$ context $=\ln q(13.12 .2016)$.

John Paul II, Encyclical letter Evangelium Vitae, http://w2.vatican.va/content/ john-paul-ii/en/encyclicals/documents/hf_jp-ii_enc_25031995_evangeliumvitae.html.

Juškevičius J., Kai kurie teisés ì gyvybę prenataliniu laikotarpiu probleminiai aspektai, "Sveikatos mokslai" 2007 No. 17 (2), pp. 764-774.

Juškevičius J., Negimusio vaiko teisinio statuso klausimai. Medicina etika ir teise apie žmogu iki gimimo. Monografija (Sud. A. Narbekovas, E. Obelenienè), Kaunas 2012. 
Kantas I., Grynojo proto kritika, Vilnius 1982 (English version: I. Kant, Critique of pure reason, transl. and ed. by P. Guyer and A. W. Wood, New York 2008, http://strangebeautiful.com/other-texts/kant-first-critique-cambridge.pdf).

Narbekovas A., Meilius K., Biotechnologijos: pagalba ar iššūkis šeimai kaip institucijai?, "Sveikatos mokslai" 2002 No. 18 (2), pp. 84-91.

Narbekovas A., Vaisingumas asmens savybe,, "Sveikatos mokslai” 2011 No. 21 (3), pp. 5-11.

The Pontifical Council for the Family, The truth and meaning of human sexuality. Guidelines for education within the family, http://www.vatican.va/roman curia/pontifical_councils/family/documents/rc_pc_family_doc_08121995_ human-sexuality_en.html.

The Pontifical Council for Pastoral Assistance to Health Care Workers, The Charter for Health Care Workers, 22, https://www.ewtn.com/library/CURIA/ PCPAHEAL.HTM (11.11.2016).

The Universal Declaration of Human Rights adopted and published by the UN General Assembly on 10 December 1948 by resolution 217A, available at: http://www.ohchr.org/EN/UDHR/Documents/UDHR_Translations/eng. pdf (13.12.2016).

Taminskas A., Mesonis G., Žmogaus orumas: konstitucinès refleksijos, "Jurisprudencija" 2014 No. 21 (4), p. 958.

Vaišvila A., Žmogaus orumas ir teisè j oruma teisinio personalizmo požiūriu (nuo statiškojo prie tampančiojo orumo sampratos), "Jurisprudencija” 2005 No. 71 (63), pp. 49-61.

Wojtyła K., Meile ir atsakomybè (Love and responsibility), Vilnius 1994, p. 174 (English version: Love and responsibility, transl. H. T. Willetts, London-New York 1981). 